\title{
数值シミュレーションによる多層地盤内および湛水浸潤時の フィンガリング現象に関する研究
}

Numerical simulation of fingering flow in multilayered aquifer and infiltration under ponded condition

\author{
齋藤 雅彦*.中平 隆** \\ Masahiko SAITO and Takashi NAKAHIRA
}

*博士（工） 神戸大学助教 自然科学系先端融合研究環 都市安全研究センター（T657-8001 神戸市灘区六甲台町 1-1） **神戸大学大学院自然科学研究科建設学専攻（干657-8001 神戸市灘区六甲台町 1-1）

\begin{abstract}
In this study, conventional saturated-unsaturated seepage analysis or two-phase flow analysis of air and water through porous media coupled with $1 / f^{-\zeta}$ model as the geostatistical model of hydraulic conductivity are carried out to investigate fingering flow caused by heterogeneity of soil or pore air. Results show that in multilayered aquifer that have relatively low permeability stratum between high permeability layers, fingering flow occur clearly under the middle stratum. In the ponded condition, the "fingering flow of air" occurs by pore-air pressure even if the variance of hydraulic conductivity is very low. The results of 3-dimensional analysis show that air flow paths are obviously changed by progress of time and water saturation distributions are more intricate than results of 2-dimensional analysis.
\end{abstract}

Key Words : vertical infiltration, fingering flow, heterogeneity, 2-phase flow analysis キーワード: 鈶直浸透, フィンガ一流, 不均一性, 気液2相流解析

\section{1. 序論}

不飽和土壌への鉛直浸透時には, 浸潤前線が不安定にな る現象, いわゆるフィンガー流が発生する場合があること が知られている ${ }^{1)}$. 従来の実験的研究により, フィンガー 流は成層土一の浸潤時 ${ }^{2)}$, また乾いた砂の単一層への散水 浸潤時 ${ }^{3)}$ など様々な条件で発生することが知られており， その発生形態については, 土の粒径や粒度分布, 初期含水 率, 浸潤強度などが関斬することが明らか炕されている

一方, 浸透流の解析手法として一般的に用いられている 飽和・不飽和浸透流解析 ${ }^{5)}$, 6), 7)では, 地盤はその透水性に 応じて透水層, 難透水層, 不透水層などに分類され, それ ぞれの層の透水係数を一つの值で代表させることが多い が, 同一の土質と考えられる層内においても, 透水係数は 空間的にばらつき, また, このようなフィンガリング現象 を数值シミュレーションによって再現しようとする場合, 地盤の諸物性值を一定と仮定する限り不可能である.

これに対し, 齋藤 ${ }^{8}{ }^{8}$ は, 確率的フラクタルモデルに基づ いた空間分布モデルと飽和・不飽和浸透流解析を組み合わ せることによって, フィンガリング現象を数值シミュレー ションによって簡易に再現するとともに, 水分特性曲線の わずかなばらつきが, 水分拡散係数の大きなばらつきにつ
ながり,これによって浸潤線が不安定になることを示して いる.

本研究では，この手法を応用し，多層地盤内に生じるフ インガリング現象の再現を試みる.

加えて, 湛水浸潤時のように初期の浸透量が大きい場合 は, 大気と接する境界付近の飽和度が急激に上昇するため, 大気と地艋内の空気の自由な交換が阻害される.このとき, 間隙内空気の圧縮とこれに伴う空気圧の上昇が生じるが, このような場における地盤内の空気の流れの性質につい ては十分に解明されていないと考えられる.

本研究では, 気液 2 相流解析を用いることによって不均 一地盤内の湛水浸潤時における空気の流れの性質につい て検討する.

\section{2. 基權方程式およひ不䭂和浸透特性}

\section{1 基确方程式}

水および空気の基礎方程式は, 連続式とダルシ一則に基 づき, 式(1)および式(2)となる. 
$\eta \frac{d S_{w}}{d P_{c}}\left(\frac{\partial P_{a}}{\partial t}-\frac{\partial P_{w}}{\partial t}\right)=\frac{\partial}{\partial x_{i}}\left\{k_{r w} \frac{k_{i j}}{\mu_{w}}\left(\frac{\partial P_{w}}{\partial x_{j}}+\rho_{w} g \frac{\partial x_{3}}{\partial x_{j}}\right)\right\}$

$\eta\left\{\left(1-S_{w}\right) \frac{d}{d P_{a}}\left(\frac{1}{\beta_{a}}\right)-\frac{1}{\beta_{a}} \frac{d S_{w}}{d P_{c}}\right\} \frac{\partial P_{a}}{\partial t}+\eta \frac{1}{\beta_{a}} \frac{d S_{w}}{d P_{c}} \frac{\partial P_{w}}{\partial t}$

$=\frac{\partial}{\partial x_{i}}\left(\frac{k_{r a}}{\beta_{a}} \frac{k_{i j}}{\mu_{a}} \frac{\partial P_{a}}{\partial x_{j}}\right)$

ここに $t$ は時間, $x_{i}$ は空間座標, $\eta$ は有効空隙率, $k_{w}, k_{r}$ はそれぞれ水と空気の相対透過保数， $k_{i j}$ は地艋の固有透過 度， $\mu_{w} ， \mu_{a}$ はそれぞれ水と空気の粘性係数， $P_{w}, P_{a}$ は水と 空気の圧力, $P_{c}$ は毛管圧 $\left(=P_{a}-P_{w}\right), S_{w}, S_{a}$ はそれぞれ水 と空気の飽和度, $\beta_{a}$ は構成体積率, $g$ は重力加速度である.

境界条件は, 圧力規定の場合,

$$
\begin{array}{ll}
\text { 水 } & P_{w}=P_{w b} \\
\text { 空気: } & P_{a}=P_{a b}
\end{array}
$$

である.ここに, $P_{w b}$ および $P_{a b}$ は, 境界上の水圧および空 気圧の規定値である. また, 流量規定境界の場合は,

$$
\begin{aligned}
& \text { 水 }:-k_{r w} \frac{k_{i j}}{\mu_{w}}\left(\frac{\partial P_{w}}{\partial x_{j}}+\rho_{w} g \frac{\partial x_{3}}{\partial x_{j}}\right) n_{i}=Q_{w b} \\
& \text { 空気: }-k_{r a} \frac{k_{i j}}{\mu_{a}} \frac{\partial P_{a}}{\partial x_{j}} n_{i}=Q_{a b}
\end{aligned}
$$

である. ここに, $Q_{w b}$ は水の流量流束の規定值， $Q_{a b}$ は流量 流束の規定值, $n_{i}$ は境界の外向き単位法線ベクトル, $\rho_{\mathrm{w}}$ は 水の密度である. ここで, $P_{a}=0($ 大気圧 $)$ として, 式(1)の左 辺第一項および式(2)を無視し， $P_{c}=-P_{w}$ とすると, 飽和・ 不飽和浸透流解析の基礎方程式が得られる.

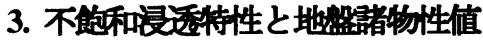

\section{1 不飾和唚远特性}

解析に必要な物性值である比透水係数 $k_{w}$ は飽和度の関 数, 飽和度 $S_{\mathrm{w}}$ は毛管圧 $\boldsymbol{P}_{c}$ の関数と考えられる. これらの 関係 (水分特性曲線) を数学的にモデル化する試みがなさ れ，多くのモデルが提案されているが，ここでは式(5)の van Genuchten の式 ${ }^{10)}$ を用いる.

$$
\begin{aligned}
S_{e}=\frac{S_{w}-S_{r}}{1-S_{r}} & =\frac{1}{\left\{1+\left(\alpha P_{c} / \rho_{w} g\right)^{n}\right\}^{m}} \\
& m=1-1 / n
\end{aligned}
$$

ここに, $\alpha, n, m$ は空隙の幾何学的な特徴から決定され るパラメータで, $n, m$ は無次元， $\alpha$ は長さの逆次元を持 つ. $S_{e}$ は有効飽和度, $S_{r}$ は残留飽和度である.

相対透過係数は有効飽和度を用いて次式で表される.

$$
\begin{aligned}
& \text { 水 }: k_{r w}=S_{e}^{\varepsilon}\left\{1-\left(1-S_{e}^{1 / m}\right)^{m}\right\}^{2} \\
& \text { 空気 : } k_{r a}=\left(1-S_{e}\right)^{\gamma}\left(1-S_{e}^{1 / m}\right)^{2 m}
\end{aligned}
$$

ここにとおよび $\gamma$ は空隙の連続性に関するパラメータで, $\varepsilon=1 / 2, \gamma=1 / 3$ である.

\section{2 地然睹物性值の空間分布}

（1）透水係数の空間分布

透水係数の空間分布は齋藤・川谷 ${ }^{11), 12)}$ によって提案され ている確率的フラクタルモデルに基づいた空間分布モデ ルを用いて発生させた. これは, 透水係数の対数変換值 $\mathrm{Y}=\log \left(k_{s}\right)$ のパワースペクトル密度関数が次式のように $f^{-\zeta}$ 型となるものであり, 実地盤における透水係数の空間分布 特性を容易に模擬し得ることを確認している.

$$
s(|f|) \propto|f|^{-\zeta}
$$

ここに, $f$ は空間周波数ベクトル, $S(|f|)$ はパワースペク トル密度，らは空間的な相関性を表すパラメータであり, 2 次元モデルの場合 $\zeta \doteqdot 2.0$ である. このとき, 自己相関 関数を指数関数で近似した場合の相関長(積分特性距離)は, 解析対象スケールの 0.1 倍程度となる.

また, 本モデルにおける $Y$ の分散は, 空間解像度(要素 数)の対数值に比例することがわかっている. すなわち, 解像度を $M$, 比例定数を $\lambda$ とすると以下のように表せる.

$$
\sigma^{2}=\lambda \log _{10} M
$$

ここに, $\sigma$ は飽和透水係数の対数值の標準偏差, 解像度 $M$ は, 領域を $M$ 個の正方形に分割することを意味する.

以上のように, 本モデルでは, 透水係数の空間分布特性 は, 相関性を表すパラメータらと, ばらつきの大きさを表

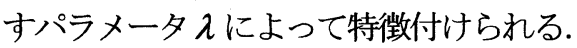

（2）不飽和浸透特性の空間分布

水分特性曲線として van Genuchten の式を用いる場合, パラメータとして $\alpha, n$, および残留飽和度 $S_{r}$ を決定する 必要がある. 本研究では, 砂質土を用いた谷中ら ${ }^{13)}$, およ

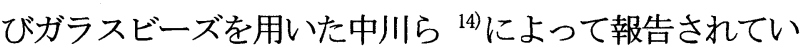
る室内試験結果に基づき, 飽和透水係数 $k_{\mathrm{s}}$ と $\alpha$ の関係を式 (11)のように決定した ${ }^{15)}$.

$$
\alpha^{-1}=-37.35 \times \log _{10} k_{s}-16.22
$$

ここに, $\alpha$ の単位は $\mathrm{cm}^{-1}, k_{s}$ の単位は $\mathrm{cm} / \mathrm{s}$ であり, $\alpha^{-1} \geq 1.0$ (cm) とする. また, 残留飽和度については, 一般的に $k_{s}$ が大きいほど $S_{r}$ は小さくなる傾向があることから， $\alpha$ と 同様に $k_{s}$ の関数として, 両者の関係を式(12)のように仮 定した ${ }^{8)}$. 


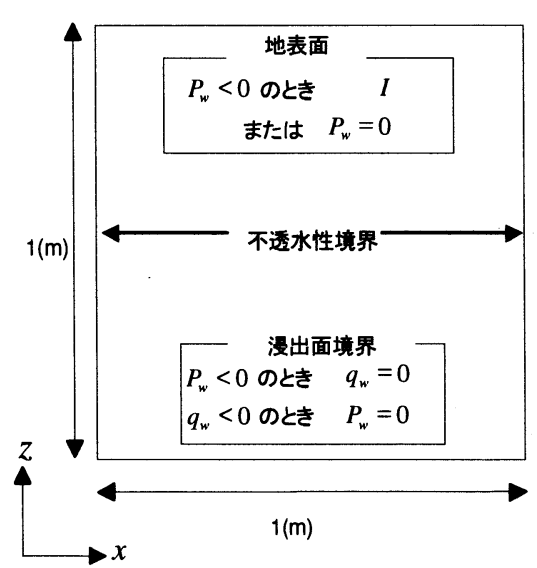

図-1 解析領域と境界条件

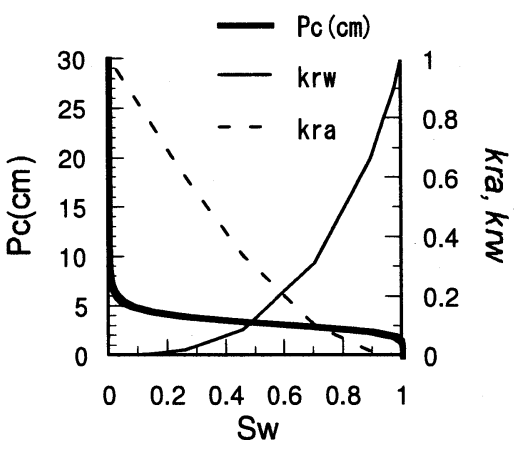

a) $k_{m}=0.3(\mathrm{~cm} / \mathrm{s})$

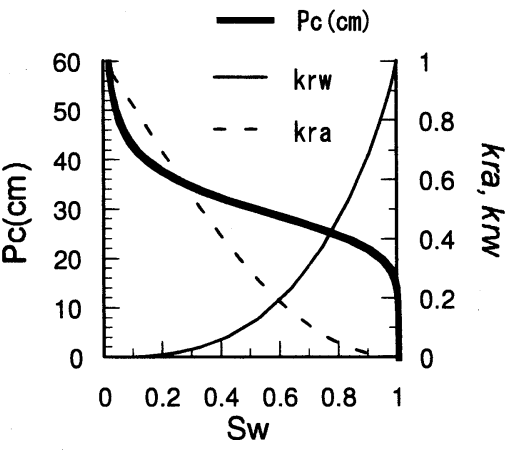

b) $k_{m}{ }^{\prime}=0.06(\mathrm{~cm} / \mathrm{s})$

図-2 水分特性曲線

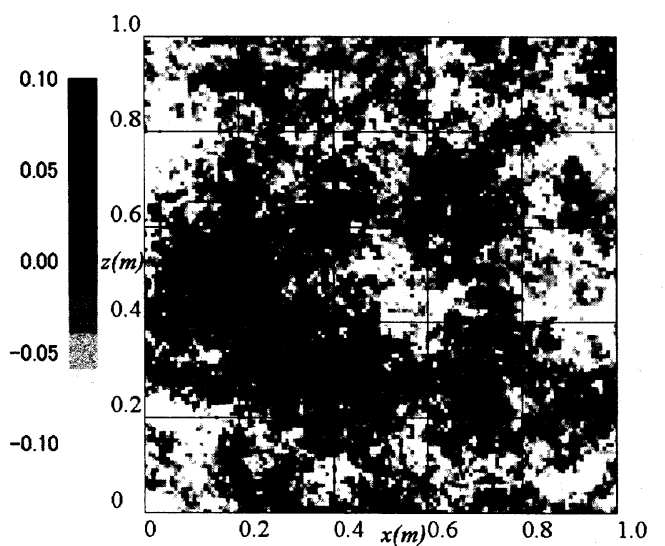

a) CASE1-1

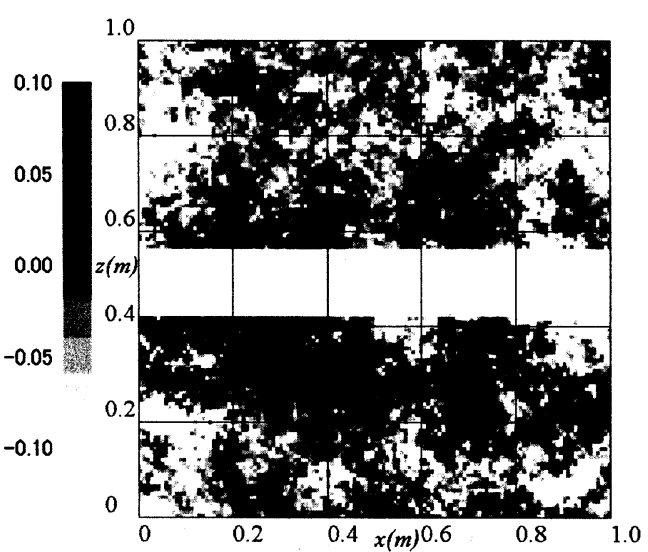

b) CASE1-2

図-3＼cjkstart飽和透水係数分布 $\left(\log _{10}\left(k_{s} / k_{m}\right)\right)$

$$
S_{r}=-0.15 \times \log _{10} k_{s}-0.2
$$

ここに, $S_{r}$ は無次元, $k_{s}$ の単位は $\mathrm{cm} / \mathrm{s}$ であり, $S_{r} \geq 0.0$ と する. パラメータ $n$ については, $k_{s}$ との明瞭な相関関係 を確認できなかったので，空間的に一定值とした。

\section{4. 多層地盤におけるフィンガリング現象の解析}

\section{1 解析条件}

図-1に対象とする解析領域及び境界条件を示す. 解析 領域は $1(\mathrm{~m}) \times 1(\mathrm{~m})$ の正方形領域とし，地表面には，一定 の浸潤強度 $I=30(\mathrm{~mm} / \mathrm{h})$ を与え, 間隙水圧が大気圧に達 したときは圧力境界として $P_{w}=0$ を与える. 側面は不透 水性境界とする．また下面は浸出面境界とする．解析領 域の要素分割数 $M$ は, 正方形要素により分割し, $M=128$ $\times 128$ (個)，式(9)におけるらは 2.0 とした.

初期条件は全領域で一定の水圧 $P_{\mathrm{w}}=-40(\mathrm{~cm})$ とした.

また, 水分特性曲線については, $n=7.0$ とし, 各要素 に対する $\alpha$ を式(14)より， $S_{\mathrm{r}}$ を式(15)よりそれぞれ求める. 図-2 に $k_{m}=0.3(\mathrm{~cm} / \mathrm{s})$ と $k_{m}{ }^{\prime}=0.06(\mathrm{~cm} / \mathrm{s})$ における水分特性 曲線を示す. 図-3 は飽和透水係数分布である. CASE1-1 は単層地盤, CASE1-2 は $14 \mathrm{~cm}$ の透水性の小さい層（中
間層) を挿入する. ここで, CASE1-1 の飽和透水係数の 幾何平均値は $k_{m}=0.3(\mathrm{~cm} / \mathrm{s}), \sigma=0.1\left(\lambda=2.37 \times 10^{-3}\right)$, CASE1-2 における中間層は, CASE1-1 の 1/5（ $k_{m}{ }^{\prime}=0.06$ $(\mathrm{cm} / \mathrm{s}))$ とした.

\section{2 解析結果と考察}

図-4 にCASE1-1 と CASE1-2 の定常状態における飽和 度分布を示す. CASE1-2では, 中間層の下部の左側には フィンガー流が流れ込まない，図-5に，定常状態にお付 る CASE1-1, CASE1-2 の流速分布を示す.ここでベクト ルの大きさは飽和透水係数 $k_{m}$ に対する比 $\left(=v_{w} / k_{m}\right)$ で表 している. CASE1-1 において見られた左側のフィンガー が, CASE1-2 では中間層を通過後見られない. 図-6に, CASE1-2 の中間層に接している下部の透水層の要素の 飽和透水係数の值を示す. $x=0.5(\mathrm{~m}) \sim x=1.0(\mathrm{~m})$ にか忖て存 在する要素内の飽和透水係数の值は, $x=0.0(\mathrm{~m}) \sim x=0.5(\mathrm{~m})$ に存在する要素における值に比べて相対的に小さいが, 不飽和時の水分拡散係数は逆に大きくなる ${ }^{8)}$. このため CASE1-2 において $x=0.5(\mathrm{~m}) \sim x=1.0(\mathrm{~m})$ の範囲でフィンガ 一流が生じると考えられる.

図-7に, CASE1-2 の $t \fallingdotseq 37(\mathrm{~min}), t \fallingdotseq 129(\mathrm{~min}) に お け る$ 飽 和度分布を示す. 上部の透水層で左端に生じていたフィ ンガーは他のフィンガーよりも早く難透水層に到達する. 


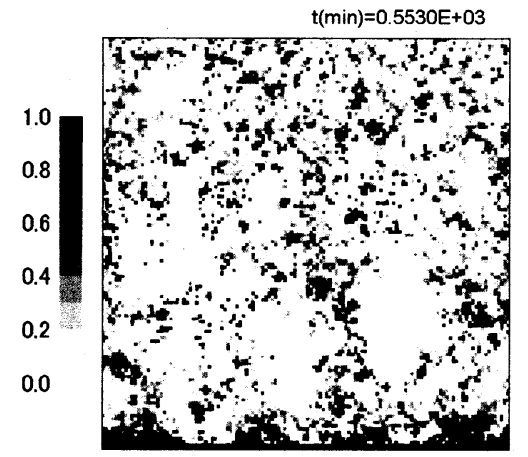

a) CASE1-1

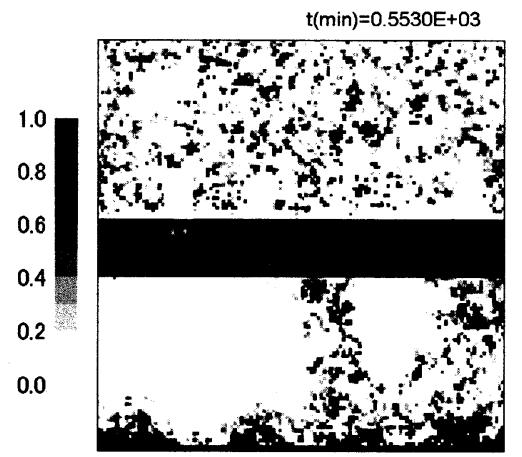

b) CASE1-2

図-4 定常状態における飽和度分布

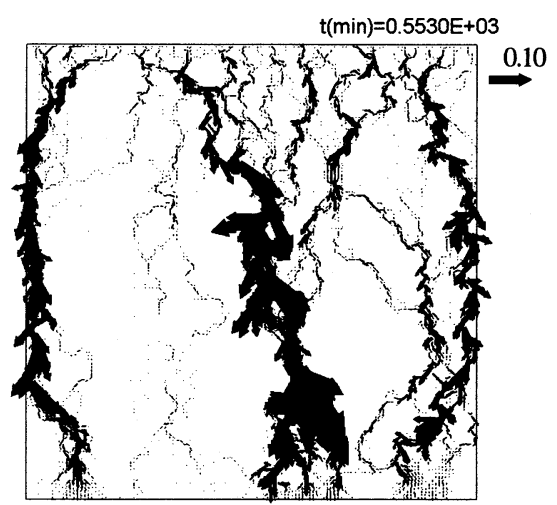

a) CASE1-1

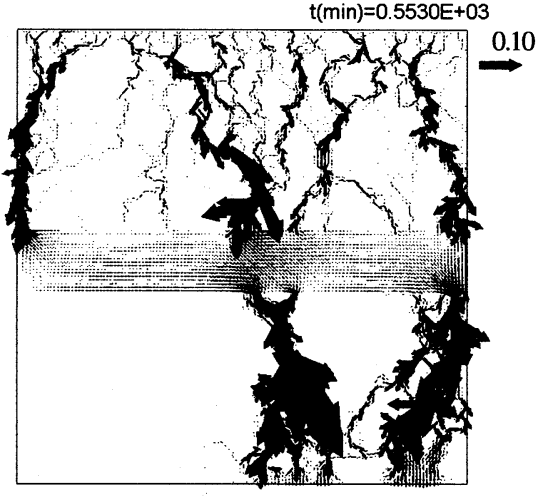

b) CASE1-2

図-5＼cjkstart定常状態における流速ベクトル分布

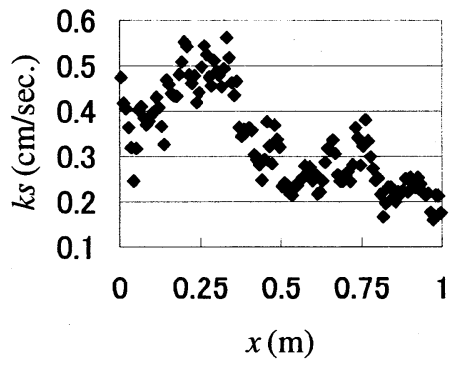

図-6 中間層直下の透水係数

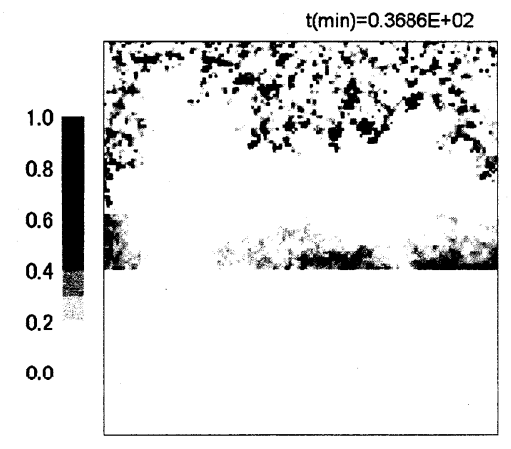

a) $t=37$ (min)

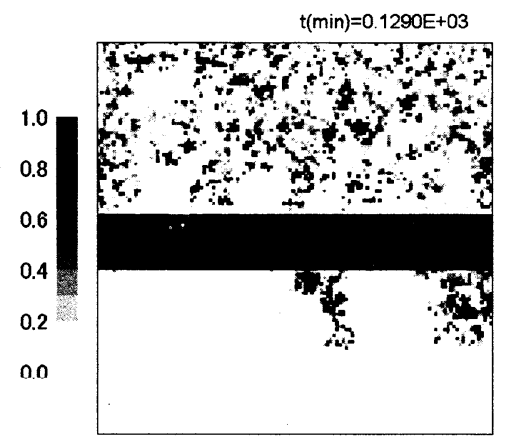

b) $t=129(\mathrm{~min})$

図-7＼cjkstart飽和度分布の時間変化 (CASE1-2)

その後, 難透水層全域が飽和領域になるように, 水分が移 動し, さらに時間が経過すると, 飽和透水係数の值の小さ い部分, つまり水分拡散係数の大きな部分からフィンガー 流が発生する.

以上から，上部透水層のフィンガー流の形態は，下部の 透水層のフィンガー流の形態に影響を及ぼさず, 下部の透 水層の上部に位置する箇所の飽和透水係数の值が影響を 与えていると考えられる.

\section{5. 湛水浸潤時における間隙空気の影響}

\section{1 解析条件}

湛水浸潤時の間隙空気の挙動について調べるため, 解析
領域の下面を不透水性境界として, 間隙空気は地表面のみ から排出されるようにする（図-8）. CASE2-1 は比較対象 として空気の流れを考慮しない場合, CASE2-2, CASE2-3 は2 相流解析である. また, CASE2-1, CASE2-2 では $\zeta=2.0$, $\sigma=0.06\left(\lambda=8.54 \times 10^{-4}\right)$, CASE2-3 では $\zeta=2.0, \quad \sigma=0.01$ $\left(\lambda=2.37 \times 10^{-5}\right)$ とした. 地表面の境界条件は水については 圧力境界 $\left(P_{w}=0\right)$ とし, 空気については浸出面境界として いる.

また, CASE3-1 は $1 \mathrm{~m} \times 1 \mathrm{~m} \times 1 \mathrm{~m}$ の 3 次元解析であり, 分割数は各辺を 32 分割, また $\zeta=3.0, \sigma=0.06\left(\lambda=7.97 \times 10^{-4}\right)$ とした. 飽和透水係数の幾何平均值はすべて $k_{m}=0.3(\mathrm{~cm} / \mathrm{s})$ である. 2 次元場の飽和透水係数分布 (CASE2-1, CASE2-2) を図-9に示寸。 


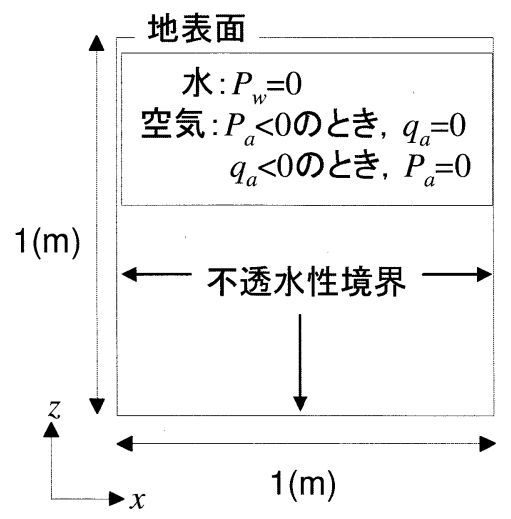

図-8 解析領域と境界条件

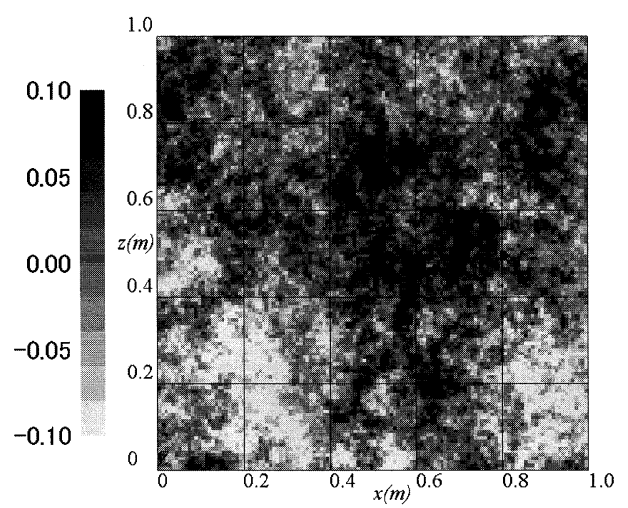

図-9 飽和透水係数分布 (CASE2-1, CASE2-2; $\left.\log _{10}\left(k_{s} / k_{m}\right)\right)$

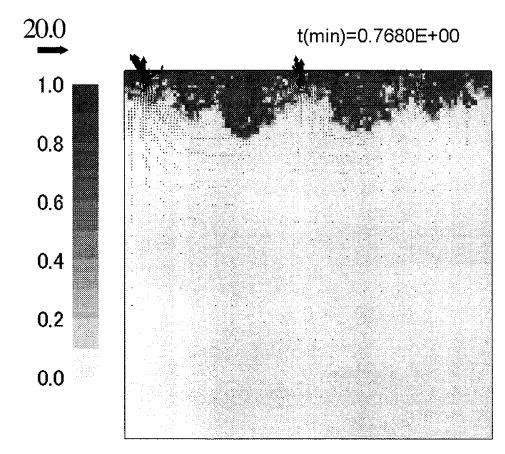

a) $t=46 \mathrm{sec}$

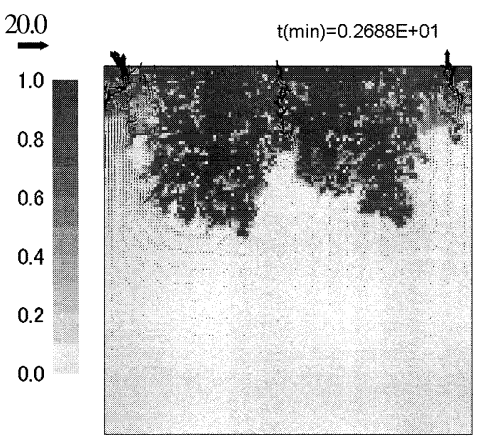

b) $t=161 \mathrm{sec}$

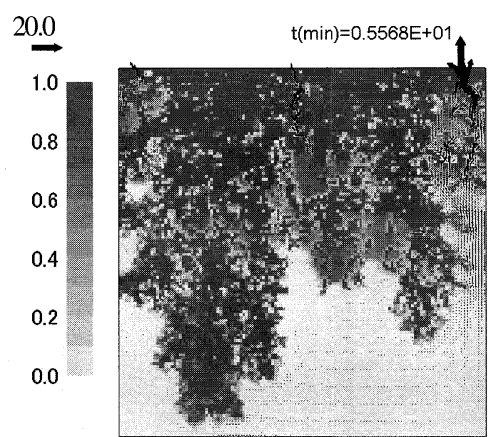

c) $t=334 \mathrm{sec}$

図-10＼cjkstart飽和度分布の時間変化と空気の流速ベクトル（CASE2-2）

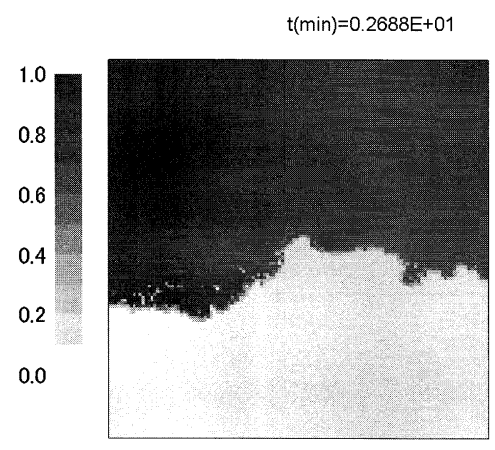

図-11 飽和度分布 (CASE2-1; $t=161 \mathrm{sec)}$

\section{2 解析結果と考察 (2 次元解析)}

図-10 に, CASE2-2 における飽和度分布の時間変化を 示寸.ここで, 矢印は空気の流速ベクトルを表している. 3 本の「空気のフィンガー流」とも呼べる空気の流速べ クトルがみられる. また, 左端に存在していた空気のフ インガー流の流速ベクトルは, 時刻 $t=334(\mathrm{sec})$ において 小さくなっている.これは, 水の浸潤線が発達し, 空気 の通り道を防いだためと考えられる，このことから，空 気のフィンガー流の形状は，水の浸潤線の状態により， 時間的に変化するようである. さらに, 空気のフィンガ 一流は水のフィンガー流よりも局所的な流れであるとい える. また, この空気の流れにより, 浸潤線が形作られ ているようである. 図-11 は, 図-10-b) と同一時刻におけ る CASE2-1（1 相流）の浸潤線を比較したものである.

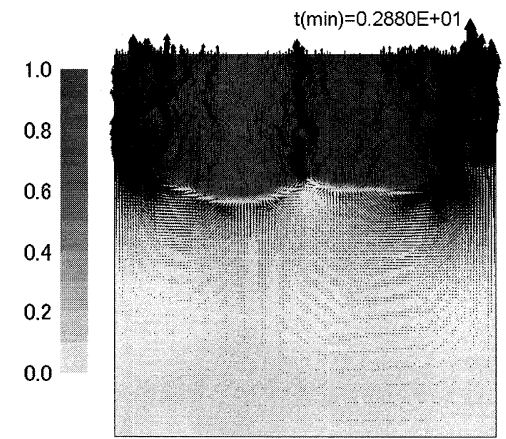

図-12＼cjkstart飽和度分布と空気の流速ベクトル（CASE2-3）

まず，浸潤線の形状について比較すると，CASE2-1にお いては影著なフィンガー流は発生していないのに対し, CASE2-2（図-10b）では概ね2 本のフィンガー流がみら れる. また, 浸潤線の速度については, CASE2-2の方が 遅い。つまり, 浸潤線の下部に存在する間隙空気の圧力 が増加するような条件でフィンガー流が発生していると き，間隙空気の圧力によって浸潤線の全体的な速度が小 さくなる.

図-12 は, CASE2-3 における飽和度分布と空気の流速 ベクトルを示したものである. この解析例では $\sigma=0.01$ としており，きわめて均一性の高い場であるが，空気の 流れの局所性は強い. このことから, 空気のフィンガー 流は, 水のフィンガー流よりも, 地盤物性值のばらつき の小さな地盤においても発生しやすいといえる. 


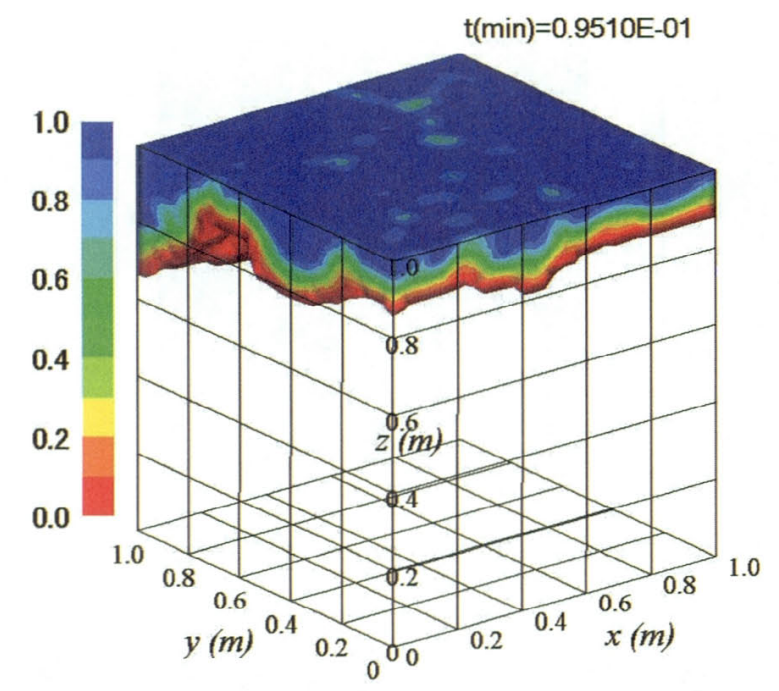

a) $t=5.7 \mathrm{sec}$

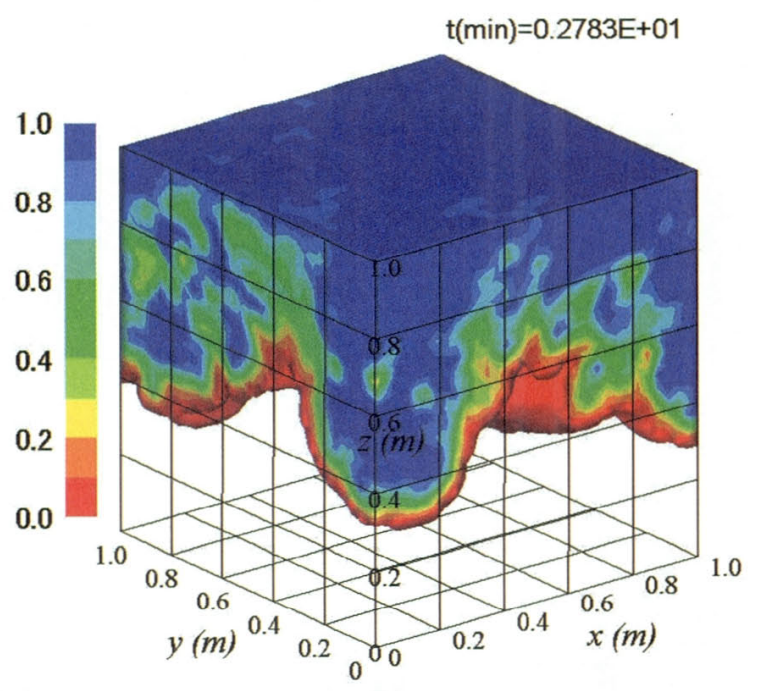

b) $t=167 \mathrm{sec}$

図-13 飽和度分布

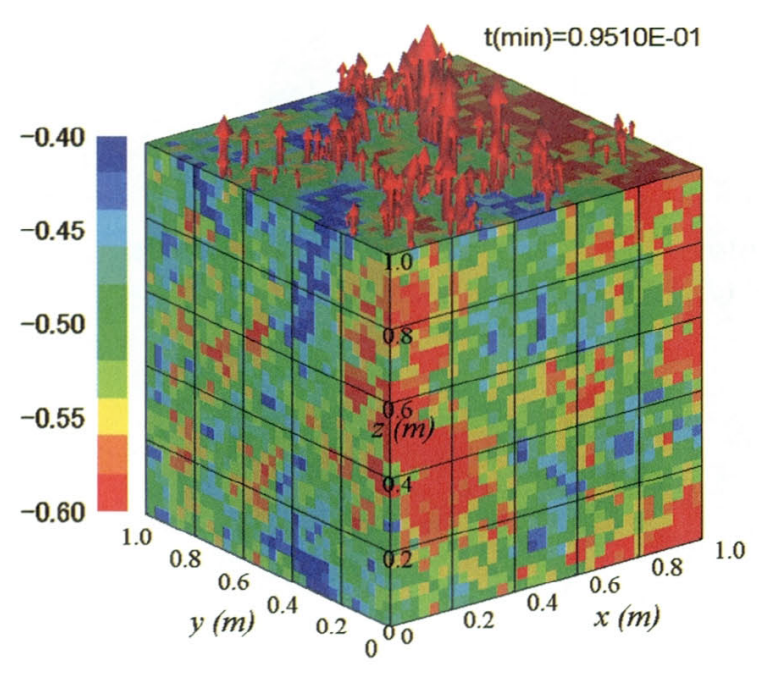

a) $t=5.7 \mathrm{sec}$

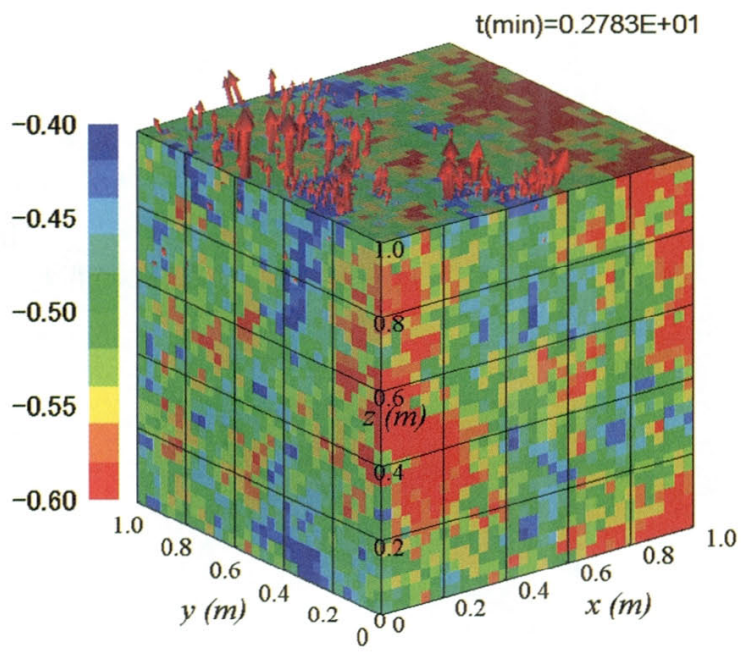

b) $t=167 \mathrm{sec}$

図-14 飽和透水係数 $\left(\log _{10} k_{s}\right)$ 分布と地表面における空気の流速ベクトル
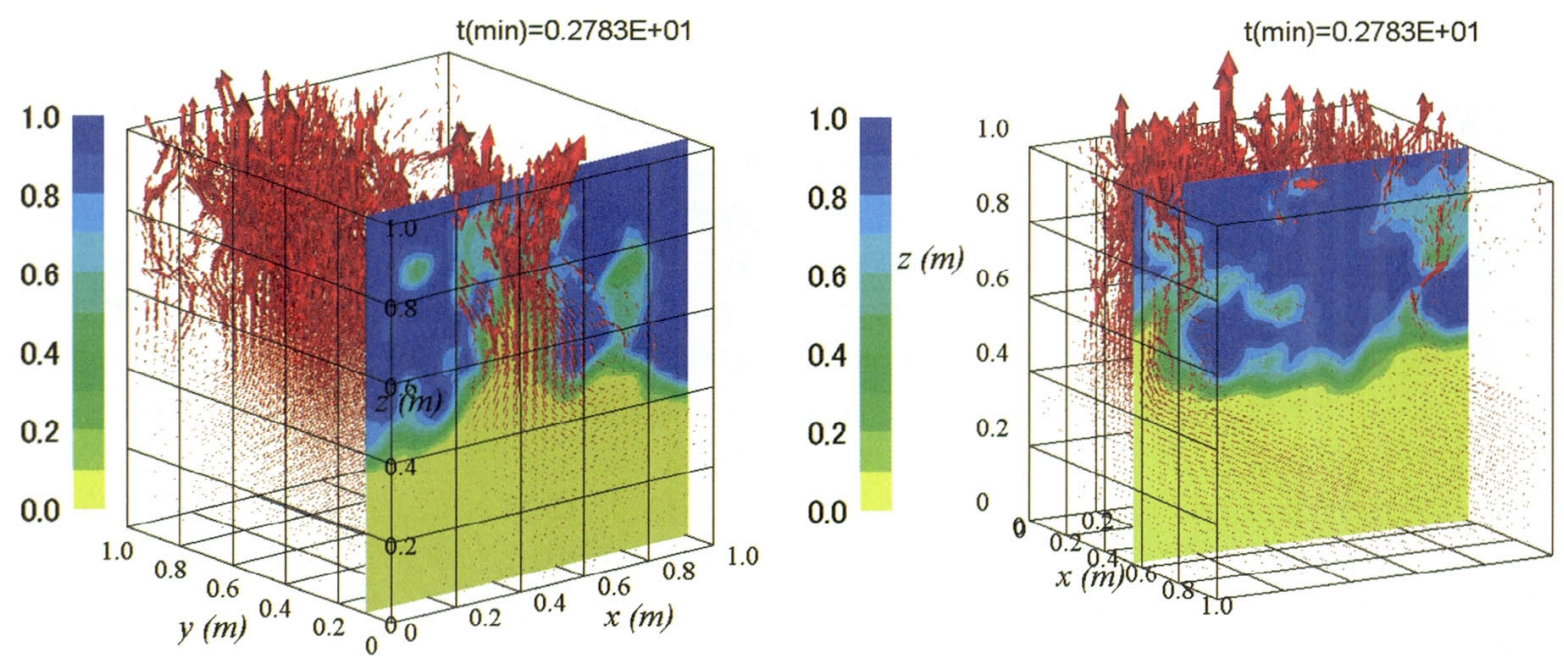

a) $y=0.1 \mathrm{~m}$ 断面

b) $x=0.55 \mathrm{~m}$ 断面

図-15 空気の流速べクトル分布と 2 次元断面におりる飽和度分布 


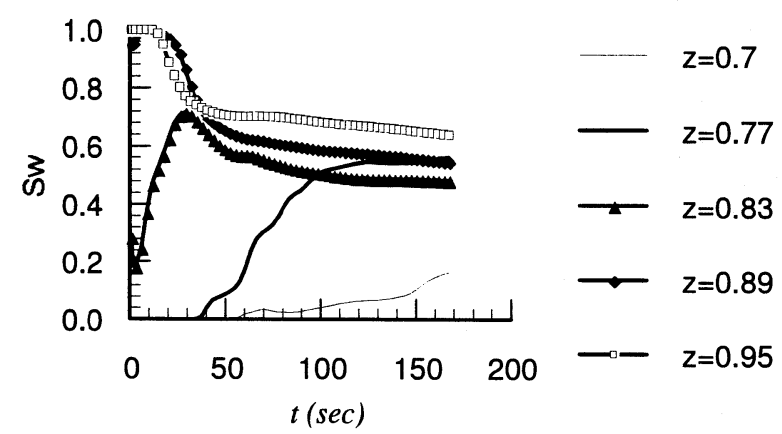

図-16 飽和度の時間変化

\section{3 解析結果と考察 (3 炊元解析)}

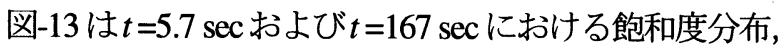
図-14 は飽和透水係数の対数值の分布と地表面における 空気の流速ベクトルを示す. また, 図-15 は空気の流速 ベクトル分布と 2 次元断面（2 断面）における飽和度分 布である.

図-13 および図-14より，浸潤の初期の段階では，比較 的飽和透水係数の大きい部分からの浸透が早く, 地表面 の広い範囲から空気の排出が生じているように見える.

一方, 時間が経過すると飽和透水係数の小さい部分の飽 和度が高くなり，逆に空気の排出は専ら飽和透水係数の 大きな部分からとなっている.

このように時間の経過とともに空気の流れる経路が変 化する模様は，2 次元解析によって得られた結果と同様 である. しかし，浸潤初期の段階では飽和状態に達して いた部分が，その後に飽和度が低下している部分が地表 面付近 $((x, y, z)=(0,0.4,0.9))$ に見られるが, このような変化は 2 次元解析では見られない. 図-16 は このような現象を詳細に見るために， $x=0 \mathrm{~m}, y=0.4 \mathrm{~m}$, $z>0.6 \mathrm{~m}$ 上のいくつかの要素における飽和度の時間変化 を表したものである.これより， $z>0.8 \mathrm{~m}$ では，一度飽和 度が上昇した後に低下しており,「空気の通路」の変化 は3 次元場ではより大規模に生じ得ることが考えられる.

また，図-15 の飽和度分布より 2 次元断面内の飽和度 分布は, 2 次元解析で得られたものより複雑な分布を示 していることがわかる．例えば，部分的に空気が封入さ れているように一部のみ飽和度が周辺よりも小さい部分 が見られる.

これより，一般に実現象は3 次元であることから，浸 潤挙動をより正確に評価するうえでは， 3 次元解析が必 要性であることを示唆する結果と思われる.

\section{6. 結論}

本研究では，多層地盤におけるフィンガリング現象, および湛水条件下の浸潤過程における「空気のフィンガ リング」について数值シミュレーションを行ない，その 特徴について調べた．以下に本研究で得た結論を示す.

1）多層地盤の場合, 透水性の低い層とその下部の透水
層の境界では, 比較的明瞭なフィンガー流が発生す る. これは，透水性の低い層の内部は飽和度が高く 水分の移動が容易であり, 下部の透水層の水分拡散 係数の大きな箇所へ水分が集中するからである. ま た，透水性の低い層が透水層によって挟まれている 場合は, 下部の透水層を流れるフィンガー流の形状 は，上部透水層のフィンガー流の形状によらない。

2）湛水条件下では, 間隙空気が水の浸潤線の下部に閉 じ込められるとき, 空気が地表面へ局所的に流れる. この「空気のフィンガー流」は, 水のフィンガー流 よりも局所的な流れである. また, 比較的地盤物性 值のばらつきの小さい地盤においても，「空気のフ インガー流」が発生する.

3)「空気のフィンガー流」は，時間の経過とともに変 化する. 特に 3 次元場ではその傾向が強く現れた. また, 飽和度分布は 3 次元解析の場合に, 2 次元解 析と比較してより複雑な分布が得られた。

\section{参考文献}

1) 宮崎毅: 環境地水学, 東京大学出版会, pp.36-37, 2000.

2) Glass, R. J., T. S. Steenhuis, and J. -Y. Parlange : Wetting front instability : 2. Experimental determination of relationships between system parameters and two-dimensional unstable flow field behavior in initially dry porous media, Water Resour. Res., 25, pp. 1195-1207, 1989.

3) Selker, J.S., T. S. Steenhuis, J. -Y. Parlange : Wetting front instability in homogeneous sandy soils under continuous infiltration, Soil Sci. Soc. Am. J., 56, pp.1346-1350, 1992.

4) 川本健, 宮崎毅, 中野政詩 : フィンガー流の形態に よる塩分溶脱効果の相違, 農業土木学会論文集, 第 186 号, pp.89-96, 1996.

5) Neuman, S.P. : Saturated unsaturated seepage by finite element, Proc., ASCE HY, Vol.99, No.12, pp.2233-2250, 1973.

6) Neuman, S.P. : Galerkin method of analyzing non-steady flow in saturated-unsaturated porous media, Finite Element Method Inflow Problem, edited by C. taylor, O. C. Zienkiewicz, R. H. Gallagher, John Wiley \& Sons, Chap.19, 1974.

7）赤井浩一, 大西有三, 西垣誠: 有限要素法による飽 和-不飽和浸透流の解析, 土木学会論文集, 第264 号, pp.87-96, 1977.

8）齋藤雅彦: 飽和・不飽和浸透流解析による不均一地 盤内のフィンガリング現象に関する研究, 水工学論 文集, 第 50 巻, pp217-222, 2006.

9) Meire, D. : Two-phase flow simulation of air storage in an 
aquifer, Water Resources Research, Vol.17, No.5, 1360-1366, 1981.

10) van Genuchten, M. T. : A closed-form equation for predicting the hydraulic conductivity of unsaturated soils, Soil Science Society American Journal, Vol.44, pp.892-898, 1980.

11）齋藤雅彦，川谷健 : 透水係数の空間分布に関する理 論的考察, 土木学会論文集, No.645/ III-50, pp.103-114, 2000.

12）齋藤雅彦，川谷健 : 透水係数の空間分布モデルの適 用性に関する一考察, 土木学会論文集, No.694/ III-57, pp.245-258, 2001.
13）谷中仁志, 石田哲郎 : 砂質土における比透水係数曲 線( $\theta-\mathrm{kr})$ の検討, 第 33 回地盤工学研究発表会, pp.1817-1818, 1998.

14）中川啓, 岩田将英, 筑紫次郎, 籾井和朗 : 不飽和-不 均一多孔媒体における物質輸送特性について : 水工 学論文集, 第 47 巻, pp.337-342, 2003.

15）齋藤雅彦, 川谷健 : 地盤の不均質を考慮した降雨浸 透・浸出過程の気液 2 相流数值シミュレーション, 水工学論文集, 第 48 巻, pp.319-324, 2004.

(2007 年 4 月 12 日 受付) 